\title{
Correlation and principal component analysis of clinical, bioelectrical and functional variables in newly diagnosed lung cancer adult patients. Pilot study
}

Justa Carmen Columbié Regüeiferos

Hospital General Santiago Dr. Juan Bruno Zayas Alfonso

Taira Teresa Batista Luna

Universidad Autonoma de Santo Domingo

Soraida Cándida Acosta Brooks

Saturnino Lora Provincial Hospital: Hospital Provincial Clinico Quirurgico Docente Saturnino Lora Torres Maylet Planas Rodriguez

Universidad de Ciencias Médicas Santiago de Cuba

Larisa Zamora Matamoros

Universidad de Oriente

Beatríz Legrá Rodríguez

Universidad de Ciencias Médicas Santiago de Cuba

Arnolis Poll Fernández

Hospital General Docente Agostinho Neto

José Luis García Bello

Universidad Autonoma de Santo Domingo

Arquímedes Montoya Pedrón

Hospital General Santiago Dr. Juan Bruno Zayas Alfonso

Maraelys Morales González

Universidad de Oriente

Julio Cesar Núñez Garcia

Universidad de Oriente

Esmirna Cascaret Fonseca

Centro Provincial de medicina Deportiva

Luis Enrique Bergues Cabrales ( $\square$ berguesc@yahoo.com )

Centro Nacional de Electromagnetismo Aplicado, Universidad de Oriente https://orcid.org/0000-00018094-392X 
Keywords: Bioelectrical impedance analysis, newly diagnosed lung cancer adult patients, Spearman's Rho correlation coefficient, association coefficient of eta, principal component analysis

Posted Date: February 22nd, 2022

DOI: https://doi.org/10.21203/rs.3.rs-1127295/v1

License: (c) (i) This work is licensed under a Creative Commons Attribution 4.0 International License. Read Full License 


\section{Correlation and principal component analysis of clinical,}

\section{2 bioelectrical and functional variables in newly diagnosed lung}

\section{3 cancer adult patients: Pilot study}

4 Justa Carmen Columbié Regüeiferos ${ }^{1}$, Taira Teresa Batista Luna ${ }^{2,3,4}$, Soraida Cándida

5 Acosta Brooks ${ }^{5}$, Maylet Planas Rodriguez ${ }^{1,6}$, Larisa Zamora Matamoros ${ }^{7}$, Beatríz Legrá

6 Rodríguez ${ }^{1,6}$, Arnolis Poll Fernández ${ }^{1,8}$, José Luis García Bello ${ }^{2,9}$, Arquímedes Montoya

7 Pedrón ${ }^{1}$, Maraelys Morales González ${ }^{2}$, Julio Cesar Núñez Garcia ${ }^{10}$, Esmirna Cascaret

8 Fonseca $^{11}$, Luis Enrique Bergues Cabrales ${ }^{12 *}$

9 'Servicio de Neumología, Hospital General Santiago "Dr. Juan Bruno Zayas Alfonso",

10 Santiago de Cuba, Cuba.

11 Universidad de Oriente, Facultad de Ciencias Naturales, Departamento de Farmacia,

12 Santiago de Cuba, Cuba.

$13{ }^{3}$ Universidad Autónoma de Santo Domingo, Recinto Nagua, Departamento de Ciencias,

14 Escuela de Física, República Dominicana.

$15{ }^{4}$ Técnica Regional del Ministerio de Educación, Nagua, República Dominicana.

$16{ }^{5}$ Servicio de Medicina Interna, Departamento de Ensayos Clínicos, Hospital General

17 Docente Provincial Saturnino Lora, Santiago de Cuba, Cuba.

$18{ }^{6}$ Universidad de Ciencias Médicas, Departamento de Fisiología, Santiago de Cuba,

19 Cuba.

$20 \quad{ }^{7}$ Universidad de Oriente, Facultad de Ciencias Naturales y Exactas, Departamento de

21 Matemática, Santiago de Cuba, Cuba.

$22{ }^{8}$ Unidad de Cuidado Intensivo, Hospital General Docente Agostinho Neto,

23 Guantánamo, Cuba. 
1 ' ${ }^{9}$ nniversidad Autónoma de Santo Domingo, Recinto San Francisco de Macorís,

2 Departamento de Ciencias, Escuela de Física, República Dominicana.

$3 \quad{ }^{10}$ Universidad de Oriente, Facultad de Ciencias Sociales, Santiago de Cuba, Cuba.

$4{ }^{11}$ Centro Provincial de Medicina Deportiva, Santiago de Cuba, Cuba.

$5{ }^{12}$ Universidad de Oriente, Centro Nacional de Electromagnetismo Aplicado,

6 Departamento de Investigación e Innovación, Santiago de Cuba, Cuba.

7

$8 \quad *$ Corresponding author and request for reprints: Luis Enrique Bergues Cabrales.

9 Departamento de Investigación e Innovación, Centro Nacional de Electromagnetismo

10 Aplicado, Universidad de Oriente, Av. Las Américas. Santiago de Cuba 90400, Cuba.

11 Phone: (53) (22) 643721, 646378, 646380, Fax: (53) (22) 646376.

12 E-mail: berguesc@yahoo.com

13

14 E-mail addresses of all authors

15 JCCR: ustacarmen@nauta.cu

16 TTBL: tairabatista@gmail.com

17 SCAB: soraidac@infomed.sld.cu

18 MPR: maylet.planas@infomed.sld.cu

19 LZO: larisa@uo.edu.cu

20 BLR: moralesmara2014@gmail.com

21 APF: arnolis17011983@gmail.com

22 JLGB: jlgarciabello@gmail.com

23 AMP: arqui6606@gmail.com

24 MMG: maraelys@uo.edu.cu

25 JCNG: jcarmen@infomed.sld.cu 
1 ECF: esmirnacascaret1966@gmail.com

2 LEBC: berguesc@yahoo.com

3

4 Abstract

5 Background: Bioelectrical impedance analysis has been used in cancer patients. The

6 aim of this study is to propose an integrated analysis of clinical, bioelectrical and

7 functional variables in newly diagnosed lung cancer adult patients for the integral

8 evaluation and possible prognostic of them.

9 Methods: This Pilot study was retrospective and cross-sectional and 23 patients aged

10 53-82 years participated in it. The electrical resistance and capacitive electrical

11 reactance were measured with the Bodystat Quadscan ${ }^{\circledR} 4000$ analyzer. The electrical

12 impedance modulus and the phase angle were calculated. The serum concentrations of

13 epidermal growth factor, CYFRA21-1 and CA 72-4 were quantified.

14 Correlations/associations among variables and the principal component analysis were 15 suggested.

16 Results: The majority of patients had tumor markers, electrical resistance and the phase

17 angle in their respective normal ranges. The capacitive electrical resistance was below

18 its normal range. Minimum, low and moderate grades of linear correlation/association

19 prevailed among studied variables. The principal components I and II were interpreted

20 as prognosis and body energetic reserve of the patient, respectively.

21 Conclusions: It is concluded that the clinical, bioelectrical and functional variables

22 allow the integral analysis and possible prognosis of newly diagnosed lung cancer adult

23 patients. The decrease of the capacitive electrical reactance is the most influence to the

24 loss of the body energetic reserve that leads to alterations of the overall health, tiredness

25 and decrease of weight and body mass index of these patients. 
1 Key words: Bioelectrical impedance analysis, newly diagnosed lung cancer adult

2 patients, Spearman's Rho correlation coefficient, association coefficient of eta, principal

3 component analysis

4

\section{$5 \quad$ Background}

6 Lung cancer is a common disease in adult patients; main cause of death of all malignant

7 tumor types; second cause of death of all types of death worldwide; and its diagnostic

8 techniques are expensive, invasive, not applicable to several patients, and not fully

9 confirmatory for the diagnosis and prognosis of lung cancer adult patients, LCAPs [1].

10 High concentrations in blood serum of Epidermal Growth Factor (sEGF), monoclonal

11 antibody that recognizes a fragment of cytokeratin 19 (sCYFRA21-1), and glycoprotein

12 TAG-72 (sCA 72- 4) tumor markers may be indicators of tumor malignancy degree and

13 poor prognosis [2, 3]. In addition, ECOG (Eastern Cooperative Oncology Group)

14 functional scales, named ECOG-fs, allow objectifying the quality of life of cancer

15 patients [1].

16 Body hydration state, body cell mass, prognosis, survival and quality of life of LCAPs,

17 sick patients and apparently healthy adult subjects (AHASs) have been related to

18 different bioelectrical variables (BBVs), as electrical resistance, $\mathrm{R}$, capacitive electrical

19 reactance, $\mathrm{Xc}$, electrical impedance modulus, $|\mathrm{Z}|$, and phase angle, $\theta$ [4-7]. Short

20 survival is observed in LCAPs for $\theta \leq 4.5^{\circ}[4,8]$. Other BBVs (e.g., $\mathrm{R} / \mathrm{H}, \mathrm{Xc} / \mathrm{H}, \mathrm{H}^{2} / \mathrm{R}$

21 and $\mathrm{H}^{2} / \mathrm{Xc}$ ) have been used too, where $\mathrm{H}$ is the height of the subject [4-9].

22 We are not aware of an integrated study involving correlation and Principal Component

23 Analysis (PCA) of patient biological variables (PBVs), tumor biological variables

24 (TBVs), and BBVs in LCAPs. Therefore, the aim of this study is to propose an 
1 integrated analysis of PBVs, TBVs and BBVs in newly diagnosed lung cancer adult

2 patients (NDLCAPs).

3

4 Methods

$5 \quad$ Ethic aspects

6 This retrospective cross-sectional Pilot study was carried out at the Pneumology Service

7 of the hospital General Santiago Dr. Juan Bruno Zayas Alfonso, Santiago de Cuba,

8 Cuba (from March 1 to September 30, 2018). It was approved by the Ethics Committee

9 (108823SC900-149, May 5, 2017) and the Scientific Council (Resolution 189/2017) of

10 this hospital, governed by the ethical standards of the Declaration of the Helsinki World

11 Medical Assembly, [10] and fulfilled with good medical clinical practices established

12 by the Ministry of Health of the Republic of Cuba [11].

13 NDLCAPs were included in this research once they, companion and witness

14 (psychologist) proceeded to the reading, agreed, and signed the Informed Consent. They

15 received previously a detailed explanation of objectives, importance and purposes of

16 this study, and requirements established for measurements (empty bladder, no smoking

17 at least $24 \mathrm{~h}$ prior, no intake of steroids at least one week before, no intake of alcoholic

18 beverages at least $24 \mathrm{~h}$ prior, fasting $2 \mathrm{~h}$ minimum, and non-performance of physical

19 exercises $12 \mathrm{~h}$ before taking measurements) [7].

20

\section{Patients}

22 The inclusion criteria were the Informed Consent, lung cancer cyto-histological

23 diagnosis and the patient received medical attention at the Pneumology Service.

24 Exclusion criteria were patient and/or family refusals to participate in this study, patients with metallic implants in the body, amputated limbs, generalized skin diseases, 
1 serious infections, and disorders of body fluids. Voluntary abandonment and death were

2 established as exit criteria. Measurements were conducted to 23 NDLCAPs aged 53-82

3 years (14 men and 9 women) with different tumor histological varieties. A numerical

4 code (from 1 to 23 ) was assigned to each patient in order of arrival.

6 Variables

7 The personal history of each patient was collected and 11 original independent variables

8 were reported: six PBVs (H, age, body weight, gender, body mass index (BMI), and

9 degree of the ECOG-fs (d-ECOG-fs); two TBVs (lung cancer stage (LCS) and lung

10 cancer histological variety (LCHV)), and three BBVs (R, Xc and $\theta)$. Furthermore, R/H,

$11 \mathrm{Xc} / \mathrm{H}, \mathrm{R} / \mathrm{H}^{2}$ and $\mathrm{Xc} / \mathrm{H}^{2}$ variables were analyzed. All these variables were quantitative,

12 except categorical variables (gender, d-ECOG-fs and LCHV). The number 1 was

13 assigned to the male gender (M) and the number 2 to the female gender $(\mathrm{F})$. The

14 numbers 1, 2, 3, 4 and 5 were allocated to LCHV small cell, large cell, squamous cell

15 carcinoma, adenocarcinoma, and non-small cell carcinoma, respectively.

16 BMI was calculated for each one of NDLCAPs from the weight $/ \mathrm{H}^{2}$ ratio (weight (in

$17 \mathrm{~kg}), \mathrm{H}$ (in m)). LCHV was confirmed by pathological anatomy. TNM staging of the

18 lung cancer was reported by the American Joint Committee on Cancer [12].

19 Furthermore, the relative change in unintentional body weight of each NDLCAPs $(\Delta \mathrm{P}$,

20 in \%) was calculated by means of $\Delta P \cong\left[\left(P_{o}-P_{e}\right) / P_{e}\right] 100 \%$, where $\mathrm{P}_{\mathrm{e}}$ was the expected

21 patient weight if he did not have cancer (estimated from the reference Table of body weight for AHASs by $\mathrm{H}$, gender and age group) and $\mathrm{P}_{\mathrm{o}}$ his measured body weight.

23 Three degrees for the decrease in $\Delta \mathrm{P}(\Delta \mathrm{P}<0)$ were established: slight $(|\Delta \mathrm{P}| \leq 5 \%)$,

24 moderate $(5<|\Delta \mathrm{P}| \leq 10 \%)$ and severe $(|\Delta \mathrm{P}|>10 \%)$ [13]. d-ECOGs-fs were $0,1,2,3,4$, 25 or $5(1,13)$. Grade 5 was not considered because no patient died during measurements. 
2 Measurement of sEGF, CYFRA21-1 and CA 72-4 tumor biomarkers

3 The basal concentration of sEGF (in $\mathrm{pg} / \mathrm{ml}$ ) was quantified with the Ultra Micro

4 Analytical System technology (SUMA ${ }^{\circledR}$, Centro de InmunoEnsayo (BioCubaFarma) La

5 Habana, Cuba). Basal concentrations of sCYFRA 21-1 (in $\mathrm{ng} / \mathrm{mL}$ ) and sCA 72-4 (in

$6 \mathrm{U} / \mathrm{mL}$ ) were quantified with the Lecto Ultra Micro Analytical System technology

7 (LECTO-SUMA ${ }^{\circledR}$, Centro de InmunoEnsayo). Both technologies are located in the

8 SUMA Laboratory of the hospital General Santiago Dr. Juan Bruno Zayas Alfonso.

9 sEGF measurement was made with UMELISA-EGF ${ }^{\circledR}$ diagnostic technique (UMELISA-

$10 \mathrm{EGF}^{\circledR}$ reagent kit was produced and supplied by the Centro de InmunoEnsayo).

11 sCYFRA 21-1 and sCA 72-4 measurements were made with the Elecsys diagnostic

12 technique (Elecsys reagent kit was produced and supplied by the Centro de

13 InmunoEnsayo, ECLISA $\left.{ }^{\circledR}\right)$.

14 It was extracted $5 \mathrm{~mL}$ of blood to each one of NDLCAPs. For sEGF, a fraction of this

15 blood was placed in a dry tube and allowed to stand for $4 \mathrm{~h}$ to obtain the serum.

16 Samples were stored at $-20^{\circ} \mathrm{C}$. The serum in aliquots of $500 \mu \mathrm{L}$ was preserved to

17 facilitate its subsequent use. Additionally, sEGF concentration of each patient was

18 referred to that of AHASs, by each gender and age group [14]. For sCYFRA 21-1 and

19 sCA 72-4, the other fraction of $5 \mathrm{~mL}$ of blood was placed in a standard sample tube and

20 left to stand for $2 \mathrm{~h}$ to obtain the serum. Samples were stored between 2 and $8{ }^{\circ} \mathrm{C}$.

21 sCYFRA 21-1 and sCA 72-4 concentrations were referred to their respective normal

22 ranges $0.1-3.30 \mathrm{ng} / \mathrm{mL}$ and $0.1-6.90 \mathrm{U} / \mathrm{mL}$, respectively [2]. Each sample was

23 identified with the patient code and the date of collection. In addition, the estrogen

24 receptor was not quantified because none of NDLCAPs had breast cancer previously. 


\section{$1 \quad$ Electric bioimpedance analyzer}

2 The Bodystat Quadscan ${ }^{\circledR} 4000$ multi-frequency analyzer (company Bodystat, LTD,

3 Douglas Isle of Man, British Isles, available at https://www.bodystat.com/) was used to

4 estimate $\mathrm{R}$ and $\mathrm{Xc}$ values. $|\mathrm{Z}|\left(|Z|=\sqrt{R^{2}+X c^{2}}\right)$ and $\theta\left(\theta=\operatorname{tg}^{-1}(X c / R)\right)$ were

5 calculated. As $|\mathrm{Z}|-\mathrm{R} \leq 3.0 \Omega$ (difference that had not statistical significance or in

6 clinics), it was presumed that $|Z| \cong R$ [7]. Consequently, we assume that $R=H / \sigma S$

7 and therefore $R / H=1 / \sigma S$ and $R / H^{2}=1 / \sigma S$, where $\sigma, \mathrm{S}$, and V were the body

8 electrical conductivity, conductor cross section, and conductor volume of each one of

9 NDLCAPs, respectively. This device operated at frequencies of 5, 50, 100 and $200 \mathrm{kHz}$;

10 nevertheless, all BBVs were reported at $50 \mathrm{kHz}$. The calibrator supplied by the

11 manufacturer $(500.0 \pm 0.1 \Omega)$ allowed evaluating the stability of this BIA analyzer at the

12 beginning and the end of the measurement in each patient.

14 Measurement procedure

15 The standardized procedure internationally to measure BBVs [4-9] was used in this

16 study. Measurements were carried out in the morning hours (from 8 to 9 am) by a

17 trained nurse. Before that, the measurement of the $\mathrm{H}$ to the nearest $0.5 \mathrm{~cm}$ was

18 conducted using the technique of the International Biological Program with the head

19 located in the Frankfort plane. The precision of this technique was $\pm 0.1 \mathrm{~cm}$. Body

20 weight was measured with a Soehnle Professional digital scale (model 2755, Soehnle

21 Industrial Solution, Backnany, Germany) with an accuracy of $\pm 0.5 \mathrm{~kg}$. Measurements

22 were made under controlled environmental conditions: temperature of $25 \pm 1^{\circ} \mathrm{C}$

23 (Sattigungs thermometer of precision $\pm 1{ }^{\circ} \mathrm{C}$, Germany), a relative humidity of $60 \pm 5 \%$

24 (Fischer Polymeter of precision $\pm 1 \%$, Germany) and a neutral environment (free of

25 field generating equipment and electromagnetic radiation). 
1 The patients were covered with light clothing and placed in a supine position on a non-

2 conductor surface, without a pillow under the head, with the arms separated at

3 approximately $30^{\circ}$ from the thorax and the legs separated approximately at an angle of

$4 \quad 45^{\circ}$ without contact between them. The skin of each patient was first cleaned with water

5 and soap, and then $70 \%$ alcohol to ensure asepsis of the areas where the electrodes

6 were attached.

7 The right tetrapolar ipsilateral method was used. The stimulating electrodes (or injection

8 electrodes of alternating electric current) were placed in the medial areas of the dorsal

9 surfaces of hands and feet, near the metacarpal and metatarsal phalangeal joints,

10 respectively. The sensing electrodes (or receiving electrodes the body electrical voltage)

11 were placed between the distal epiphyses of the radius and the ulna, at the level of the

12 pisiform eminence, as well as at the midpoint between both malleoli, respectively. The

13 distance between the sensing and stimulating electrodes was $5.0 \mathrm{~cm}$ and measured with

14 a standard measuring tape (model RT-144, Wintape Measuring Tape Co., Ltd,

15 Guangdong, China) of $0.1 \mathrm{~cm}$ precision. Electrocardiogram electrodes (model APR-

16 020, All Pro Corporation Company, Quingdao, China) were used. The material of each

17 electrode was Silver/Silver Chloride (Ag/AgCl).

19 Comparison between bioelectrical parameters of NDLCAPs and AHASs

20 Values of $\mathrm{R}, \mathrm{R} / \mathrm{H}, \mathrm{R} / \mathrm{H}^{2}, \mathrm{Xc}, \mathrm{Xc} / \mathrm{H}, \mathrm{Xc} / \mathrm{H}^{2}$, and $\theta$ were reported individually for each

21 one of NDLCAPs. From these individual values, the mean \pm standard deviation

22 (standard error of the mean $=$ standard deviation $/ \sqrt{\mathrm{N}}$, where $\mathrm{N}$ was the total number of

23 patients) of $\mathrm{R} / \mathrm{H}, \mathrm{Xc} / \mathrm{H}$ and $\theta$ were calculated and referenced with their respective

24 normal ranges reported for AHASs $\left((\mathrm{R} / \mathrm{H})_{\mathrm{r}},(\mathrm{Xc} / \mathrm{H})_{\mathrm{r}}\right.$, and $\left.\theta_{\mathrm{r}}\right)$ [15], by gender, and age

25 groups 17-59 and 60-80. The standard error of the mean was used in comparisons of 
1 means of $\mathrm{R} / \mathrm{H}$ with $(\mathrm{R} / \mathrm{H})_{\mathrm{r}}, \mathrm{Xc} / \mathrm{H}$ with $(\mathrm{Xc} / \mathrm{H})_{\mathrm{r}}$, and $\theta$ with $\theta_{\mathrm{r}}$ to homogenize the sample

2 by gender and age group due to the biological individuality.

\section{Spearman's rho correlation coefficient}

5 The estimator of Spearman's rank correlation coefficient (r) was used to determine the

6 degree of linear correlation between pairs of variables mentioned above. This linear

7 correlation was significant statistically when $\mathrm{p} \leq 0.05$ (significance level). For

8 Medicine, Akoglu [16] suggested open intervals for $r$ but some its values were not

9 included between two contiguous of them. Therefore, we proposed: none $(r=0.0)$,

10 minimal $(0.0<\mathrm{r} \leq 0.2)$, low $(0.2<\mathrm{r} \leq 0.5)$, moderate $(0.5<\mathrm{r} \leq 0.7)$, good $(0.7<\mathrm{r} \leq$

$110.9)$, very good $(0.9<\mathrm{r}<1.0)$ and perfect $(\mathrm{r}=1.0)$.

\section{Eta correlation coefficient}

14 The eta correlation/association coefficient $(\eta)$ was calculated from the formula reported 15 by Smith [17]. It was applied to variables that had not linear correlation and allowed to 16 know if there was a curvilinear relationship between them. We suggested ranges for $\eta$

17 (in analogy with $\mathrm{r}$ ): none $(\eta=0.0)$, minimal $(0.0<\eta \leq 0.2)$, low $(0.2<\eta \leq 0.5)$,

18 moderate $(0.5<\eta \leq 0.7)$, good $(0.7<\eta \leq 0.9)$, very good $(0.9<\eta<1.0)$ and perfect $(\eta$ $19=1.0)$.

\section{Principal Components Analysis}

22 We used PCA descriptive statistical technique to reduce the dimensionality and

23 determine the similar groups of variables because an eleven-dimensional graphic (11

24 independent variables) for the representation of 23 NDLCAPs would be impossible to visualize, as reported Johnstone and Lu [18]. 
1 Maximum number of principal components (PCs) was 11 and represented by PCi $(\mathrm{i}=1$,

$2 \ldots, 11)$, which are linear combinations of 11 original variables. Main PCs that provided

3 more information were selected from the Kaiser criterion (eigenvalues greater than 1).

4 A threshold percentage of $40 \%$ was fixed to select the highest variable weights for each

5 one of PCs chosen. PCs that contributed little information were removed. For this,

6 different graphic strategies were analyzed: 1) outliers graphic chart (distance chart of

7 Mahalonobis versus observation); 2) sedimentation graphic (chart of eigenvalues versus

8 number of components); 3) score graphic (projection chart in the plane of all patients);

9 4) influence graphic (projection chart in the plane of all variables); 5) double projection

10 graphic (projections of all NDLCAPs and variables in the plane of PCs were

11 simultaneously represented. In these last three graphic were visualized four quadrants:

12 Quadrant I (top right), Quadrant II (top left), Quadrant III (bottom left), and Quadrant

13 IV (bottom right).

14 These graphical strategies were also showed when the pair ( $\mathrm{R}, \mathrm{Xc})$ was substituted by

15 the pair $(\mathrm{R} / \mathrm{H}, \mathrm{Xc} / \mathrm{H})$ or $\left(\mathrm{R} / \mathrm{H}^{2}, \mathrm{Xc} / \mathrm{H}^{2}\right)$ in PCA for the same six PBVs, two TBVs and $\theta$.

16 Furthermore, all these variables were labeled for a best presentation of results obtained

17 from correlation (linear and curvilinear) and PCA: age $\left(\mathrm{X}_{1}\right)$, gender $\left(\mathrm{X}_{2}\right)$, patient weight

$18\left(\mathrm{X}_{3}\right), \mathrm{H}\left(\mathrm{X}_{4}\right), \mathrm{R}\left(\mathrm{X}_{5}\right), \mathrm{Xc}\left(\mathrm{X}_{6}\right), \theta\left(\mathrm{X}_{7}\right), \mathrm{d}-\mathrm{ECOG}-\mathrm{fs}\left(\mathrm{X}_{8}\right)$, tumor stage $\left(\mathrm{X}_{9}\right), \mathrm{LCHV}\left(\mathrm{X}_{10}\right)$,

$19 \operatorname{BMI}\left(\mathrm{X}_{11}\right), \mathrm{R} / \mathrm{H}\left(\mathrm{X}_{12}\right), \mathrm{Xc} / \mathrm{H}\left(\mathrm{X}_{13}\right), \mathrm{R} / \mathrm{H}^{2}\left(\mathrm{X}_{14}\right)$ and $\mathrm{Xc} / \mathrm{H}^{2}\left(\mathrm{X}_{15}\right)$.

20 PCA and $\mathrm{r}$ were analyzed in the Minitab ${ }^{\circledR} 14$ statistical program (Minitab Inc for

21 Windows, 2003, free software, National Institute of Standards and Technology,

22 Pennsylvania State University, USA, https: //www.minitab.com/en-

$23 \mathrm{mx} /$ products/minitabs). This program ran on a computer (Department of Mathematics,

24 Universidad de Oriente, Santiago de Cuba, Cuba) with Windows 8 operating system

25 with 2.6 GB RAM; 64 bit, 64 processor, Inter R core tm. The duration of the statistical 
1 processing of the data was approximately $2 \mathrm{~s}$. Data will be kept for 15 years in the

2 Pneumology Service of the hospital General Santiago Dr. Juan Bruno Zayas Alfonso.

3

\section{$4 \quad$ Results}

\section{$5 \quad$ Original independent variables}

6 Hypertension was observed in $56.52 \%$ (seven men and six women) of NDLCAPs, and

7 two men and a women ingested diuretics. Dehydration was not clinically observed in

8 NDLCAPs. Cachexia and overweight were observed clinically in three and five

9 NDLCAPs, respectively.

10 Table 1 showed the code; age; gender; $\mathrm{H} ; \mathrm{P}_{\mathrm{o}} ; \Delta \mathrm{P}$; d-ECOG-fs; LCHV; LCS; sEGF,

11 sCYFRA 21-1, and sCA 72-4 concentrations; and R, R/H, Xc, Xc/H, and $\theta$ values of

12 NDLCAPs. M, age group 60-80 years and adenocarcinoma in $60.87 \%$ prevailed. The

$13 \mathrm{M} / \mathrm{F}$ ratio was 1.56 (14/9). Stage IV lung cancer (65.22\%, eight men and seven women)

14 and d-ECOG-fs 3 (65.22 \%, eight men and seven women) prevailed. Furthermore, $\Delta \mathrm{P}>$

150 was observed in $56.52 \%$ (seven men and six women) of NDLCAPs. The rest of

16 patients (43.48\%, seven men and three women) had severe (6), moderate (1) and slight

17 (3) decreases in $\Delta \mathrm{P}$.

18 The mean \pm standard error of sEGF, sCYFRA 21-1 and sCA 72-4 concentrations for

19 NDLCAPs and AHASs were shown in Table 2 for each age group and gender. Low

20 average sEGF (except for females of the 46 to 60 age group) and high sCYFRA 21-1 in

21 NDLCAPs were observed respect to those for AHASs by each age group and gender.

22 Majority of NDLCAPs had normal concentrations of these three biomarkers.

23 Nevertheless, some patients had sEGF (26.09\%), sCYFRA $21(43.48 \%)$ and sCA $72-4$

$24(34.78 \%)$ concentrations increased. 
1 Table 3 showed the mean \pm standard deviation (standard error of the mean) of $\mathrm{R} / \mathrm{H}$,

$2 \mathrm{Xc} / \mathrm{H}$ and $\theta$ (for NDLCAPs), and $(\mathrm{R} / \mathrm{H})_{\mathrm{r}},(\mathrm{Xc} / \mathrm{H})_{\mathrm{r}}$ and $\theta_{\mathrm{r}}$ (for AHASs) by age group and

3 gender. Women AHASs, women had higher values of $(\mathrm{R} / \mathrm{H})_{\mathrm{r}}$ and $(\mathrm{Xc} / \mathrm{H})_{\mathrm{r}}$ and lower

4 values of $\theta_{\mathrm{r}}$ than men AHASs for each age group, being noTable for the 17 to 59 age

5 group. Furthermore, men and women of the 60 to 80 age group showed higher values of

$6(\mathrm{R} / \mathrm{H})_{\mathrm{r}}$, and lower values of $(\mathrm{Xc} / \mathrm{H})_{\mathrm{r}}$ and $\theta_{\mathrm{r}}$ than those of the 17 to 59 age group for each

7 gender. For both age groups, female NDLCAPs showed lower R/H, Xc/H, and $\theta$

8 average values than those of female AHASs, whereas men NDLCAPs had higher R/H

9 average values, a slight decrease of their $\mathrm{Xc} / \mathrm{H}$ and $\theta$ average values than those of men

10 AHASs. Female patients showed $\mathrm{R} / \mathrm{H}$ and $\theta$ values lower than those of male patients for

11 the 17 to 59 age group, not for the 60 to 80 age group. Female patients showed an

12 increase in $\mathrm{Xc} / \mathrm{H}$ compared to men patients of both age groups. Furthermore, $\mathrm{R} / \mathrm{H}$ and

$13 \mathrm{Xc} / \mathrm{H}$ values of male and female patients of the 17 to 59 age group were smaller than

14 their respective values in the 60 to 80 age group for both genders. Male patients in the

1517 to 59 age group had higher value of $\theta$ than those the 60 to 80 age group.

16 Nevertheless, it was similar in female patients of both age groups.

17 Respect to $(\mathrm{R} / \mathrm{H})_{\mathrm{r}},(\mathrm{Xc} / \mathrm{H})_{\mathrm{r}}$ and $\theta_{\mathrm{r}}, \mathrm{R} / \mathrm{H}$ values were distributed below $(39.13 \%)$, above

$18(8.70 \%)$ and in the normal range $(52.17 \%) ; \mathrm{Xc} / \mathrm{H}$ values were concentrated below

$19(60.87 \%)$, above (4.35\%) and in the normal range (34.78\%). 21.74, 21.74 and $56.22 \%$

20 of $\theta$ values had below, above and in the normal range, respectively. For male patients,

$21 \mathrm{R} / \mathrm{H}$ values were grouped below (35.71\%), above (14.29\%) and in the normal range

$22(50.00 \%) ; 64.29,7.14$ and $28.57 \%$ of them had their $\mathrm{Xc} / \mathrm{H}$ values below, above and in

23 the normal range, respectively; and $\theta$ values had below (14.29\%), above (7.14 \%) and

24 in the normal range (78.57\%). For female patients, $\mathrm{R} / \mathrm{H}$ values were congregated below

$25(44.44 \%)$ and in the normal range $(55.56 \%) ; \mathrm{Xc} / \mathrm{H}$ values were concentrated below 
$1 \quad(55.56 \%)$ and in the normal range (44.44\%); and 33.33, 44.44 and $22.23 \%$ of $\theta$ values

2 had below, above and in the normal range, respectively. Cachectic and overweight had

3 their $\mathrm{R} / \mathrm{H}$ values in the normal range, whereas $\mathrm{Xc} / \mathrm{H}$ and $\theta$ values were distributed

4 outside their respective normal ranges (Table 3).

5

6 Spearman's rank correlation coefficient

7 Table 4 showed the estimator of $\mathrm{r}$ and its associated probability $\mathrm{p}$ (in brackets) for each

8 pair of independent variables. $\mathrm{H}$ had a linear, good and negative correlation with

9 gender; and linear, moderate and positive correlation with $\mathrm{P}_{\mathrm{o}}$. The gender and $\mathrm{R}$ had a

10 linear, low and positive correlation. Xc had a linear, low and negative correlation with

11 age. The d-ECOG-fs had a linear, low and positive correlation with gender; and linear,

12 low and negative correlations with $\mathrm{P}_{\mathrm{o}}$ and $\mathrm{H}$. BMI and $\mathrm{P}_{\mathrm{o}}$ had a linear, good and positive

13 correlation.

14 The R/H had a linear, moderate and positive correlation with gender; linear, moderate

15 and negative correlation with $\mathrm{H}$; linear, good and positive correlation with $\mathrm{R}$; and linear,

16 low and positive correlation with d-ECOG-fs. Xc/H had linear, low and positive

17 correlations with gender and $\mathrm{R}$; linear, moderate and positive correlation with $\mathrm{R} / \mathrm{H}$; and

18 linear, good and positive correlation with Xc. Furthermore, $\mathrm{R} / \mathrm{H}^{2}$ had linear, good and

19 positive correlations with gender and R; linear, good and negative correlation with $\mathrm{H}$;

20 linear, very good and positive correlation with $\mathrm{R} / \mathrm{H}$; linear, moderate and positive

21 correlation with $\mathrm{Xc} / \mathrm{H}$; and linear, low and positive correlation with d-ECOG-fs.

22 Additionally, $\mathrm{Xc} / \mathrm{H}^{2}$ had a linear, very good and positive correlation with $\mathrm{Xc} / \mathrm{H}$; linear,

23 good and positive with Xc; linear, moderate and positive correlations with gender, $\mathrm{R} / \mathrm{H}$

24 and $\mathrm{R} / \mathrm{H}^{2}$; linear, moderate and negative correlation with $\mathrm{T}$; and linear, low and positive 
1 correlation with R. All these correlations were significant for $95 \%$ confidence because

$2 \mathrm{p} \leq 0.05$. The rest of the variables were not linearly correlated (Table 4).

\section{$4 \quad$ Eta correlation coefficient}

5 Values of $\eta$ revealed that the gender had good association with $\mathrm{H}$ and $\mathrm{R} / \mathrm{H}^{2}$; moderate

6 association with $\mathrm{R} / \mathrm{H}$ and $\mathrm{Xc} / \mathrm{H}^{2}$. In addition, d-ECOG-fs had moderate association with

$7 \quad \mathrm{R} / \mathrm{H}$ and $\mathrm{R} / \mathrm{H}^{2}$. The rest of variables had minimum and low associations (Table 5).

\section{Principal Components Analysis}

10 Although graphics of outliers were not shown, it was revealed the non-existence of

11 outliers (all points were below the default reference line (5.568 fixed in the Minitab ${ }^{\circledR} 14$ 12 statistical program) when the pair $(\mathrm{R}, \mathrm{Xc}),(\mathrm{R} / \mathrm{H}, \mathrm{Xc} / \mathrm{H})$ or $\left(\mathrm{R} / \mathrm{H}^{2}, \mathrm{Xc} / \mathrm{H}^{2}\right)$ was included

13 in PAC. Furthermore, eigenvalues, eigenvectors, proportion and cumulative proportion

14 and variable weights by each one of PCs were shown for pairs (R, Xc) (Table 6); (R/H,

$15 \mathrm{Xc} / \mathrm{H})($ Table 7$)$ and $\left(\mathrm{R} / \mathrm{H}^{2}, \mathrm{Xc} / \mathrm{H}^{2}\right)($ Table 8$)$. Tables 6, 7 and 8 showed that first five,

16 four and four PCs prevailed, respectively.

17 The first five (Table 6) and four (Tables 7 and 8) PCs prevailed. In Table 6, variables

18 most correlated to PC1 were $\mathrm{H}$ (negatively), $\mathrm{P}_{\mathrm{o}}$ (negatively) and d-ECOG-fs

19 (positively). Variables most correlated negatively to PC2 were Xc, R and BMI.

20 Variables most correlated to PC3 were age (positively) and Xc (negatively). Variables

21 most correlated to PC4 were age (negatively), $\theta$ (negatively) and R (positively).

22 Variables most correlated to PC5 were the LCS (positively) and LCHV (negatively).

23 Variables most correlated to PC1 were $\mathrm{H}$ (negatively) and the gender (positively).

24 Variables most correlated (negatively) to PC2 were $\mathrm{Xc} / \mathrm{H}$ and the BMI. Variables most 25 correlated (positively) to PC3 were the age and the LCHV (Table 7). 
1 Variables most correlated to $\mathrm{PC} 1$ were $\mathrm{H}, \mathrm{R} / \mathrm{H}^{2}$ (positively) and the gender (negatively).

2 Variables most correlated (negatively) to PC2 were the BMI, $\mathrm{Xc} / \mathrm{H}^{2}$ and $\mathrm{P}_{\mathrm{o}}$. Variables

3 most correlated (positively) to PC3 were the age and LCHV (Table 8).

4 Positions of each one of independent variables and NDLCAPs in each quadrant are

5 showed in a two-dimensional photograph of an eleven-dimensional reality (Figure 1).

6 Influence charts (Figures 1a,c,e) and score graphics (Figures 1b,d,f) were showed for

7 the ordered pair $(\mathrm{R}, \mathrm{Xc})($ Figures $1 \mathrm{a}, \mathrm{b})(\mathrm{R} / \mathrm{H}, \mathrm{Xc} / \mathrm{H})($ Figures $1 \mathrm{c}, \mathrm{d}) \mathrm{o}\left(\mathrm{R} / \mathrm{H}^{2}, \mathrm{Xc} / \mathrm{H}^{2}\right)$

8 (Figures 1e,f) included in PCA.

9 For the ordered pair $(\mathrm{R}, \mathrm{Xc})$ included in PCA (Figure 1a), variables were located in each

10 quadrant: Quadrant I (age), Quadrant II (H), Quadrant III ( $\mathrm{P}_{\mathrm{o}}, \theta, \mathrm{Xc}$ and BMI) and

11 Quadrant IV (gender, R, d-ECOG-fs, LCS and LCHV). Similar distribution of these

12 variables was observed when in PCA was included the ordered pair $(\mathrm{R} / \mathrm{H}, \mathrm{Xc} / \mathrm{H})$

13 (Figure 1c) or $\left(\mathrm{R} / \mathrm{H}^{2}, \mathrm{Xc} / \mathrm{H}^{2}\right)$ (Figure 1e), except for Xc (changed from Quadrant III to

14 Quadrant IV) and d-ECOG-fs (changed from Quadrant IV to Quadrant I).

16 Discussion

17 Non-small cell type, male gender, age group 60-80 years, adenocarcinoma histological 18 variety and advanced stages (IIIB and IV) prevail in NDLCAPs confirm results reported

19 in $(1,12)$. The $M / F=1.56$ agrees with the current trend of increasing the number of

20 lung cancer women (M/F tends to 1 in next years) due to changes in their lifestyle and

21 smoking habits, aspects that may justify why adenocarcinoma has displaced squamous

22 cell carcinoma [1].

23 The negative correlation between $\mathrm{H}$ and gender confirms that men are generally taller

24 than women, aspect corroborated with correlations of gender with $\mathrm{H}, \mathrm{R} / \mathrm{H}$ and $\mathrm{R} / \mathrm{H}^{2}$; and

25 correlations of $\mathrm{H}$ with $\mathrm{R} / \mathrm{H}$ and $\mathrm{R} / \mathrm{H}^{2}$. Moderate correlation between $\mathrm{H}$ and $\mathrm{P}_{\mathrm{o}}$ 
1 corroborates that decrease/increase in $\mathrm{P}_{\mathrm{o}}$ does not lead necessarily to decrease/increase

2 of $\mathrm{H}$. Despite good correlation between $\mathrm{BMI}$ and $\mathrm{P}_{\mathrm{o}}$, severe decrement in $\Delta \mathrm{P}$ is better

3 predictor than $\mathrm{P}_{\mathrm{o}}$ and $\mathrm{BMI}$ for the evaluation of malnutrition, tumor activity (due to

4 catabolism), poor prognosis, low quality of life, and short survival of LCAPs [13]. d-

5 ECOG-fs does not depends on gender is corroborated by low correlation between them.

6 Low and negative correlations of d-ECOG-fs with $\mathrm{P}_{\mathrm{o}}$ and $\mathrm{H}$ indicate that the increase of

7 d-ECOG-fs is not necessarily associated to decrease of $\mathrm{P}_{\mathrm{o}}$ and $\mathrm{H}$, and d-ECOG-fs is

8 subjective (depends on patient criterion and the physician appreciation). Non lineal

9 correlation between d-ECOG-fs and LCS may be explained by predominance of stages

10 IIIB and IV in NDLCAPs, in agreement with [19] and in contrast with [20].

11 sEGF, sCYFRA 21-1 and sCA 72-4 concentrations in their respective normal ranges for

12 most of NDLCAPs with no history of breast cancer are in contract with high

13 concentrations reported in LCAPs $[3,21]$. The large standard deviation/standard errors

14 of the mean of three biomarkers may be due to the biological individuality among

15 NDLCAPs and marked variability of their values (normal and increased respect to those 16 in AHASs).

17 Minimum linear correlation/association between d-ECOG-fs and $\theta$ is an unexpected

18 result because both variables are separately indicators of the deterioration of the general

19 condition of health and unfavorable prognosis of LCAPs [1, 4-6, 13]. This may be

20 explained because d-ECOG-fs is a subjective variable whereas $\theta$ value is quantitative,

21 and/or d-ECOG-fs 3 and normal $\theta$ values prevail in the majority of NDLCAPs. As a

22 result, general health of each one NDLCAPS has not been essentially affected yet by the

23 presence of LCHV, corroborating small differences between means \pm standard errors of

$24 \theta_{\mathrm{r}}$ and $\theta$ for each age group and gender. 
1 The minimum/low correlation degree and low/moderate association degree of LCS with

2 BBVs may be explained because stages IIIb and IV prevail in the $82.6 \%$ of NDLCAPs

3 (no receive any anti-cancer therapy and $13.04 \%$ of them take only diuretics), in

4 agreement with Toso and colleagues [4], who report that distribution of the impedance

5 vector is the same for both stages in LCAPs.

6 Correlation of gender and $\mathrm{H}$ with $\mathrm{R} / \mathrm{H}$ and $\mathrm{R} / \mathrm{H}^{2}$, and high degrees of correlation and

7 association of $\mathrm{R} / \mathrm{H}^{2}$ with $\mathrm{d}-\mathrm{ECOG}$-fs corroborate that $\mathrm{R} / \mathrm{H}^{2}$ may offer information more

8 approximated, respect to $\mathrm{R}$ and $\mathrm{R} / \mathrm{H}$, of body electrical conductor volume of NDLCAPs.

9 Distributions of $\mathrm{R} / \mathrm{H}$ values contradict that $\mathrm{R} / \mathrm{H}$ does not change in LCAPs with stages

$10 \mathrm{IIIb}$ and IV [4], and agree with findings of Nwosu and colleagues [6]. Furthermore, the

11 non-prevalence of highest $\mathrm{R} / \mathrm{H}$ values, respect to its normal range, verifies the non-

12 dehydration observed clinically in NDLCAPs, in contrast with Cerchietti and colleagues

13 [22]. These findings confirm that dehydration/overhydration of any individual is closely

14 related to the increase/decrease of $\mathrm{R}, \mathrm{R} / \mathrm{H}$ and $\mathrm{R} / \mathrm{H}^{2}$ [4-7]. Patients with Codes 10 and

1516 should be dehydrated by high $\mathrm{R} / \mathrm{H}$ values, in contrast with clinical observations, and

16 explained from their cachexia and severe decrease in $\Delta \mathrm{P}$ (decrease of waist/hip ratio)

17 and therefore decrease of body electrical conductor area/volume. The decrease/increase

18 of $\mathrm{R} / \mathrm{H}$ values in NDLCAPs may be also due to the retention/release of a high water

19 amount by the inadequate/activation secretion of their antidiuretic hormones. Increase

20 of sEGF, sCYFRA 21-1 and sCA72-4 concentrations, and decrease of R/H are only

21 observed in one patient (Code 21); therefore, we discard the retention of total body

22 water due to the increase in hormonal activity (associated with the lung cancer growth)

23 [19]. Hormonal processes are decreased in elderly patients [23]. These aspects may

24 explain why $\mathrm{R} / \mathrm{H}$ and $(\mathrm{R} / \mathrm{H})_{\mathrm{r}}$ average values in female patients for the 17 to 59 and 60 to

2580 age groups differ. Additionally, higher mean of $\mathrm{R} / \mathrm{H}$ and $(\mathrm{R} / \mathrm{H})_{\mathrm{r}}$ values in the 60 to 
180 age group compared to those in their respective 17-59 age groups may be explained

2 because elderly individuals (NDLCAPs and AHASs) have decrease their total body

3 fluids due to the decrease in osmolority, number of nephrons, percentages of glomeruli

4 and the ability of the kidney to concentrate urine by the increase vasopressin secretion,

5 among others [23]. That is why, R/H average values of NDLCAPs of the 60 to 80 age

6 groups are similar for both genders.

$7 \quad$ Variability in PBVs, TBVs and BBVs explain why we recommend the individual

8 integrated analysis of each one of them respect to its normal range, instead of

9 comparison of their means between NDLCAPs and AHASs. Furthermore, TBVs and

10 PBVs are necessary but not sufficient to evaluate integrally NDLCAPs. Therefore, we

11 add BBVs to this integrated analysis.

12 Correlations between $\mathrm{R} / \mathrm{H}$ and $\mathrm{R} / \mathrm{H}^{2}, \mathrm{R} / \mathrm{H}$ and $\mathrm{R}$, and $\mathrm{R} / \mathrm{H}^{2}$ and $\mathrm{R}$ may explain the

13 increase/decrease of $\mathrm{R} / \mathrm{H}$ in NDLCAPs from the decrease/increase of $\sigma$

$14 \quad\left(\sigma=1 / \rho=\sum_{i=1}^{m} q_{i} v_{i} n_{i}+\sum_{j=1}^{k} q_{j} v_{j} n_{j}\right)$, where $\mathrm{q}_{\mathrm{i}, \mathrm{j}}, \mathrm{v}_{\mathrm{i}, \mathrm{j}}$ and $\mathrm{n}_{\mathrm{i}, \mathrm{j}}(\mathrm{i} \neq \mathrm{j})$ are the electric charge,

15 velocity and concentration of the $i$-th positively charged carrier $(i=1, \ldots, m$; e.g.,

16 sodium, magnesium, calcium and potassium ions; and positively charged molecules in

17 moving) and $\mathrm{j}$-th negatively charged carrier $(\mathrm{j}=1, \ldots, \mathrm{k}$; e.g., chlorine, phosphates,

18 bicarbonate and sulphate ions; electrons and negatively charged molecules in moving),

19 respectively. Changes in $\mathrm{v}_{\mathrm{i}, \mathrm{j}}$ and $\mathrm{n}_{\mathrm{i}, \mathrm{j}}(\mathrm{i} \neq \mathrm{j})$ of these charged carriers lead to alterations in

$20 \sigma$ and therefore the hydric state of NDLCAPs/LCAPs.

21 The non-linear correlation between $\mathrm{R}$ and $\mathrm{Xc}$, and the moderate correlations of $\mathrm{R} / \mathrm{H}$

22 with $\mathrm{Xc} / \mathrm{H}$, and $\mathrm{R} / \mathrm{H}^{2}$ with $\mathrm{Xc} / \mathrm{H}^{2}$ confirm that in graphics that show confidence regions

23 (Xc versus $\mathrm{R}, \mathrm{Xc} / \mathrm{H}$ versus $\mathrm{R} / \mathrm{H}$, and $\mathrm{Xc} / \mathrm{H}^{2}$ versus $\mathrm{R} / \mathrm{H}^{2}$ ) should appear the tolerance

24 rectangles (50,75 and $90 \%)$ and not the tolerance ellipses, in agreement with Luna and 
1 colleagues [7]. Correlations of the gender with $\mathrm{Xc} / \mathrm{H}$ and $\mathrm{Xc} / \mathrm{H}^{2}$ confirm that overweight

2 prevails in women NDLCAPs, in agreement with Chooi and colleagues [24].

3 Accumulated explained variances between 48.0 and $52.0 \%$ (Tables 6-8) by PC1 and

$4 \quad$ PC2 may be due to biological individuality of NDLCAPs (complex, open and non-

5 linear system); amount, type and variability of original independent variables analyzed;

6 minimum/low/moderate linear correlation and association among some of them.

7 Despite, PC1 and PC2 are only considered in this study by the following biophysical

8 and clinical reasons: 1) they corroborate the above discussed; 2) selection of PCs and

9 variables that most contribute to them do not depend on the inclusion of the pair (R,

$10 \mathrm{Xc}),(\mathrm{R} / \mathrm{H}, \mathrm{Xc} / \mathrm{H})$ or $\left(\mathrm{R} / \mathrm{H}^{2}, \mathrm{Xc} / \mathrm{H}^{2}\right)$ in PCA because PBVs, TBVs and BBVs are

11 characteristic of each patient. 3) PC2 is selected and no PC3 because $\mathrm{Xc}, \mathrm{Xc} / \mathrm{H}$ and

$12 \mathrm{Xc} / \mathrm{H}^{2}$ weights in PC2 are greater than those in PC3. Furthermore, BMI (in PC2) is

13 better predictor than age (in PC3) for the general health evaluation and prognosis of

14 NDLCAPs. 4) PC2 is chosen and no PC4 because BMI and $\mathrm{Xc} / \mathrm{H}$ (in PC2) are better

15 predictors than age and $\mathrm{R} / \mathrm{H}$ (in PC4). 5) Intersection of the positioning projections of

16 NDLCAPs on PC1 and PC2 is not observed in the score graphics (Figures $1 \mathrm{~b}, \mathrm{~d}, \mathrm{f}$ ).

17 The general health of NDLCAPs may be represented by the ordered pair (PC1, PC2),

18 instead of the ordered pair $(\mathrm{R}, \mathrm{Xc})$ or $(\mathrm{R} / \mathrm{T}, \mathrm{Xc} / \mathrm{T})$ [7], where $\mathrm{PC} 1$ and $\mathrm{PC} 2$ may be

19 interpreted as the prognosis and body energy reserve of NDLCAPs, respectively. This

20 prognosis may be unfavorable (PC1 positive values) or favorable (PC1 negative values).

21 Body energy reserve accumulates (PC2 negative values) or spends (PC2 positive

22 values). For PC1, favorable prognostic indicators for NDLCAPs occur for the male

23 gender; LCHV that less prevail; increases in $\mathrm{H}, \mathrm{P}_{\mathrm{o}}, \theta$ and $\mathrm{Xc}$; and decreases in d-ECOG-

24 fs, LCS, R, R/H, R/H $\mathrm{H}^{2}, \mathrm{Xc} / \mathrm{H}, \mathrm{Xc} / \mathrm{H}^{2}$, and age. For PC2, indicators of depletion/loss of

25 body energy reserve of NDLCAPs happen for the female gender; the LCHV that less 
1 prevail; increases in $\mathrm{H}$ and age; and decreases in $\theta, \mathrm{P}_{\mathrm{o}}, \mathrm{R}, \mathrm{R} / \mathrm{H}, \mathrm{R} / \mathrm{H}^{2}, \mathrm{Xc} / \mathrm{H}, \mathrm{Xc} / \mathrm{H}^{2}$,

2 BMI, d-ECOG-fs, and LCS. This brings about that PC5 (Table 6) is not considered in

3 this study, in addition to reasons above-mentioned.

4 During writing process of this paper (3 years later initiated this study), NDLCAPs that

5 die in the short time (two first years after they are diagnosed) located in Quadrant I;

6 those that die after 2 years after diagnosed distributed in Quadrants IV (survival of these

7 patients will be smaller than 5 years); cured cancer patients up to now with good general

8 condition of health concentrated in Quadrant III (tumors of these patients will reach

9 their complete remissions in the future); and cancer patients under treatment up to now

10 concentrated in Quadrant II (these patients will have long survivals (greater than 5 years

11 after diagnosed) with good/acceptable general health). Furthermore, the unfavorable

12 prognosis is corroborated in $83.3 \%$ of NDLCAPs that are located in Quadrant I (EGC,

13 LGT, ITR, RSF and JLR) and Quadrant IV (NHB, OSP, NLB, EGM and ECP). Two

14 deceased patients (ODR and OGC) are located in the vicinity of PC2 between

15 Quadrants III and IV. A patient (OMR) who is located in Quadrant II does not die from

16 cancer but from global heart failure. These aspects may confirm adequate interpretations

17 of PC1, PC2 and each quadrant. As a result, NDLCAPs place in Quadrants I and IV at

18 the moment of their diagnosis is very probable that evolve towards to the death in a

19 short relatively time. If this hypothesis is confirmed, PCA may be a useful tool in

20 oncology for the integral evaluation and prognosis of NDLCAPs when they receive

21 their respective anti-cancer therapies. For this, a further longitudinal study will be

22 required.

23 From bioelectrical point of view, low $\mathrm{Xc} / \mathrm{H}$ values in the majority of NDLCAPs is

24 explained by Luna and colleagues [7] from increase of cell membrane electric capacity,

$25 \mathrm{C}_{\mathrm{m}}\left(\mathrm{Xc}=1 /\left(2 \pi \mathrm{fC}_{\mathrm{m}}, \mathrm{f}=50 \mathrm{kHz}\right)\right.$, due to the increase of the amount of electrical charge 
1 on both sides of the cell membrane $(\mathrm{Q})$; the relative electrical permittivity $\left(\varepsilon_{\mathrm{r}}\right) /$ electrical

2 susceptibility $\left(\chi_{\mathrm{e}}\right)$ of cell membrane lipid; and decrease of the transmembrane potential

3 of the cancer cell $\left(\mathrm{V}_{\mathrm{m}}\right)$. For this, the equivalent electrical model of the cell membrane is

4 the parallel flat plate capacitor $\left(\mathrm{C}_{\mathrm{m}}=\mathrm{Q} / \mathrm{V}_{\mathrm{m}}=\varepsilon_{\mathrm{r}} \varepsilon_{\mathrm{o}} \mathrm{A} / \mathrm{d}=\left(1-\chi_{\mathrm{e}}\right) \varepsilon_{\mathrm{o}} \mathrm{A} / \mathrm{d}\right)$, where $\varepsilon_{\mathrm{o}}$ is the

5 electrical permittivity of the vacuum; A and d are the area and the thickness of the

6 cellular membrane, respectively. Decrease of $\mathrm{V}_{\mathrm{m}}$ have been associated with neoplastic

7 transformation, cell division, depolarization of the cancer cell, weak electric coupling

8 among cancer cells, failure of the contact inhibition mechanism, depletion of adenosine

9 triphosphate and failure of the sodium/potassium pump, interior-exterior ionic

10 imbalance of the cancer cell, body water imbalance and its three compartments in the

11 cancer patient differences in cancer electrical properties respect to hose of normal

12 tissue, among other disorders [7, 25, 26].

$13 \chi \chi_{\mathrm{e}} / \varepsilon_{\mathrm{r}}$ may be increased by temperature (discarded because NDLCAPs and room

14 temperatures keep constants); contaminations (for example, toxic compounds and waste

15 products generated by the tumor), fat perforation by peroxidation lipid (probably caused

16 by reactive oxygen species and free radicals); and own defects of cellular aging (BBVs

17 are altered in AHASs and NDLCAPs of the 60 to 80 age group respect to those of the

1817 to 59 age group. The increase of $\chi_{\mathrm{e}} / \varepsilon_{\mathrm{r}}$ supposes that $\mathrm{Q}$ displaces and accumulates,

19 leading to the induction of an electric field cellular membrane that opposes to the

20 physiological electric field existent at the cellular membrane (minus gradient of $\mathrm{V}_{\mathrm{m}}(-$

$\left.21 \nabla \mathrm{V}_{\mathrm{m}}\right)$ ). Furthermore, the increase of $\chi_{\mathrm{e}} / \varepsilon_{\mathrm{r}}$ may indicate changes in the composition,

22 mobility, and electrical and mechanical properties of lipids in cancer cell membranes,

23 aspect that may be related to the dyslipidemia in the majority of NDLCAPs.

24 Dyslipidemia has been associated with the growth, aggressiveness and metastasis in

25 LCAPs [27] and in children with different types of cancer [7]. 
1 From thermodynamic point of view, low $\mathrm{Xc} / \mathrm{H}$ values may be due to losses of body

2 energy reserves that may lead to the tiredness and the fatigue that NDLCAPs refer,

3 being remarkable for the 60 to 80 age group (negative correlation between Xc and age),

4 in agreement with $[4,5,7]$. This may explain why d-ECOG-fs is not linearly correlated

5 and minimally associated with $\mathrm{Xc}, \mathrm{Xc} / \mathrm{H}$ and $\mathrm{Xc} / \mathrm{H}^{2}$ and not only from several patients

6 have their $\mathrm{Xc} / \mathrm{H}$ values in the normal range. NDLCAPs with marked depletion of body

7 energy reserves may explain nutritional status deterioration in them (cachexia, and/or

8 decreases in $\mathrm{P}_{\mathrm{o}}, \Delta \mathrm{P}$ and $\mathrm{BMI}$ documented in some NDLCAPs). Consequently,

9 inadequate general conditions of health of them (corroborated by prevalence of $d$ -

10 ECOG-fs 3 and 4). These energetic losses may occur when the amount of heat

11 transmitted to the environment through human body parts increases by the increase in

12 the total dissipation of losses $\left(\mathrm{P}_{\text {dissipated }}\right)$. This $\mathrm{P}_{\text {dissipated }}$ originates in the organism by the

13 increase of its associated dissipation factor, which increases when the equivalent

14 electrical resistance and the equivalent electrical capacity at body level increase too,

15 since the harmonic frequency remains constant $(50 \mathrm{kHz})$.

16 The complete depletion of NDLCAPs body energy reserve would occur for the highest

17 value of $\mathrm{P}_{\text {dissipated }}$ (heat completely transmitted to the environment) and therefore they

18 would die, in contrast with the fact that NDLCAPs are alive at the time of their

19 diagnosis. To avoid this, transmitted heat is limited by the induction of a thermal

20 resistance $\left(\mathrm{R}_{\mathrm{T}}\right)$ in the organism that is responsible of temperature difference between the

21 body and the environment $\left(\Delta \mathrm{T}, \Delta T=P_{\text {dissipated }} R_{T}\right)$.

22 As the body temperature of each patient and the environmental temperature remain

23 constants during the measurements, $\Delta \mathrm{T}$ may be considered constant, which supposes

24 that $\mathrm{P}_{\text {dissipated }}$ decreases by a certain proportion and $\mathrm{R}_{\mathrm{T}}$ increases by the same proportion

25 (verified because $\mathrm{R} / \mathrm{H}$ mean value is higher than $(\mathrm{R} / \mathrm{H})_{\mathrm{r}}$. Decrease in $\mathrm{P}_{\text {dissipated }}$ is a 
1 measure of the increase in body entropy variation because $\mathrm{R}$ and $\mathrm{R}_{\mathrm{T}}$ increase and it may

2 be compensated making more capacitive the human body (increase of electrical capacity

3 at the cellular/tissue/body level) that leads to a decrease of $\mathrm{Xc}, \mathrm{Xc} / \mathrm{H}$ and $\mathrm{Xc} / \mathrm{H}^{2}$ in

4 NDLCAPs. Consequently, R and Xc may be interpreted as body energy losses and

5 reserves. An energy imbalance of Xc/R ratio may lead to an unfavorable prognosis of

6 NDLCAPs. By contrast, an energy balance between Xc and R may explain why most of

$7 \theta$ values are in their normal range for NDLCAPs. These findings agree with Luna and

8 colleagues [7].

9 The prevalence of minimal, low and moderate degrees of linear correlation/association

10 among PBVs, TBVs and BBVs may be due to variables of the psycho-neuro-endocrine-

11 immune system (NDLCAPs are bio-psychosocial beings [28]) are not considered.

12 Another reason may be that dependent and independent variables are indirectly related

13 by different ways. Firstly, the dependent variable is a function of one variable that in

14 turn depends on another and so on until the last variable is related to the independent

15 variable. Secondly, the dependent variable depends on multiple independent variables

16 that interact among them. Thirdly, the relationship between dependent and independent

17 variables is affected by the influence of confusing (influence on both independent and

18 dependent variables), intervening (affect the dependent variable but cannot be measured

19 or manipulated) and/or moderating (alter the effect that an independent variable has on

20 the dependent variable) variables. Consequently, all these variables are necessary but

21 not sufficient conditions (whenever the cause is produced do not implicate that always

22 cause change in the effect). Therefore, it becomes difficult to interpret NDLCAPs

23 biophysical states (non-linear and open systems) and establish a cause-effect

24 relationships and possible prognosis of them. This may be explained because none of

25 these variables are state variables (i.e., temperature, pressure, volume, entropy, Gibbs 
1 free energy, Helmholtz free energy, enthalpy, chemical potential) that describe the state

2 of a dynamical system (open or not) [7, 29-31]. These state variables may be related

3 with heat and work that make the human body in presence of a cancer type. For

4 instance, changes in patient volume is a measure of losses of unintentional body weight

5 the patient and cachexia; variations of patient entropy, Gibbs free energy, Helmholtz

6 free energy, enthalpy, chemical potential, heat and work are a measure of body disorder

7 induced by the cancer in it. Therefore these thermodynamic variables should be

8 included in this integrated analysis for the characterization and possible prognostic of

9 NDLCAPs.

\section{Conclusions}

12 In conclusion, the clinical, bioelectrical and functional variables allow the integrated

13 analysis and possible prognostic of NDLCAPs. The decrease of Xc is the most

14 influence to losses of body energy reserve that lead to alteration of the overall health,

15 tiredness and decreases of the weight and body mass index of these patients.

17 List of abbreviations

18 LCAPs, lung cancer adult patients; sEGF, Epidermal Growth Factor; sCYFRA21-1,

19 fragment of cytokeratin 19; sCA 72- 4, glycoprotein TAG-72; ECOG, Eastern

20 Cooperative Oncology Group; H, height of the subject; AHASs, apparently healthy

21 adult subjects; BBVs, bioelectrical variables; R, electrical resistance; Xc, capacitive

22 electrical reactance; $|\mathrm{Z}|$, electrical impedance modulus; $\theta$, phase angle; $\mathrm{R} / \mathrm{H}$, electrical

23 resistance/height of the subject; $\mathrm{Xc} / \mathrm{H}$, capacitive electrical reactance/height of the

24 subject; $\mathrm{H}^{2} / \mathrm{R}$, electrical resistance/(height of the subject) ${ }^{2} ; \mathrm{H}^{2} / \mathrm{Xc}$, (capacitive electrical

25 reactance/height of the subject $)^{2} ;(\mathrm{R} / \mathrm{H})_{\mathrm{r}}$, normal range of $\mathrm{R} / \mathrm{H} ;(\mathrm{Xc} / \mathrm{H})_{\mathrm{r}}$, normal range of 
$1 \mathrm{Xc} / \mathrm{H} ; \theta_{\mathrm{r}}$, normal range of $\theta$; PCA, Principal Component Analysis; PBVs, patient

2 biological variables; TBVs, tumor biological variables; NDLCAPs, newly diagnosed

3 lung cancer adult patients; BMI, body mass index; d-ECOG-fs, degree of the ECOG-fs;

4 LCS, lung cancer stage; LCHV, lung cancer histological variety; M, male gender; F,

5 female gender; TNM, Tumor, nodule and metastasis; $\Delta \mathrm{P}$, unintentional body weight of

6 each NDLCAPs; $\mathrm{P}_{\mathrm{e}}$, expected patient weight if he did not have cancer; $\mathrm{P}_{\mathrm{o}}$, measured

7 body weight; $\mathrm{Ag} / \mathrm{AgCl}$, Silver/Silver Chloride; $\mathrm{N}$, total number of patients.

\section{Declarations}

10 Ethics approval and consent to participate

11 This study is approved at the hospital General Santiago "Dr. Juan Bruno Zayas

12 Alfonso", Santiago de Cuba, Cuba. The final protocol was approved by the Ethics

13 committee (Current Controlled trials BIACANCER108823SC900-149; May 5, 2017)

14 and Scientific Board (Resolution 189/2017; June 7, 2017) of the hospital Infantil Sur

15 Antonio María Béguez César, Santiago de Cuba. Name of the register of this Pilot study

16 is BIACANCER and its registration data is July 6, 2017 at the Universidad de Ciencias

17 Médicas, Santiago de Cuba, Cuba. Date of enrolment of the first participant in this Pilot

18 study is September 4, 2017. Written Informed Consent is obtained from each participant

19 before entering the trial.

20

21 Consent for publication

22 Not applicable

24 Availability of data and materials

25 All datasets generated or analyzed during the current study appear explicitly in Tables. 


\section{Competing interest}

3 The authors declare that the research was conducted in the absence of any commercial

4 or financial relationships. We declare no competing interests.

$6 \quad$ Funding

7 JCCR, SCAB, MPR, BLR, APF, AMP, JCNG and ECF are supported by the hospital

8 General Santiago “Dr. Juan Bruno Zayas Alfonso” (grant 108823SC-900-149). LZM,

9 MMG and LEBC received grant support from the Universidad de Oriente (grant 9812).

10 Facultad de Ciencias, Universidad de Santo Domingo, República Dominicana, covers

11 the cost of this manuscript once approved; therefore, TTBL, JLGB and LEBC

12 acknowledge this support. Furthermore, the data of this study belongs to the hospital

13 General Santiago "Dr. Juan Bruno Zayas Alfonso". This financial support is not used in

14 the design of this protocol, the collection, analysis and/or interpretation of data, as well

15 as in writing of this manuscript. Authors do no received direct funding. Additionally,

16 there is not external funding source.

\section{Authors' contributions}

19 Study concepts: JCCR, SCAB, LEBC. Study design: JCCR, SCAB, MMG, LEBC. Data

20 acquisition: JCCR, TTBL, SCAB, MPR, BLR, APF, JLGB, JCNG, ECF. Quality

21 control of data and algorithms: JCCR, MPR, LZM, MMG, LEBC. Data analysis and

22 interpretation: JCCR, TTBL, SCAB, MPR, LZM, BLR, APF, JLGB, AMP, MMG,

23 JCNG, ECF, LEBC. Statistical analysis: JCCR, LZM, LEBC. Manuscript preparation:

24 JCCR, SCAB, LZM, MMG, LEBC. Manuscript editing: JCCR, LEBC. Manuscript review: JCCR, TTBL, SCAB, MPR, LZM, BLR, APF, JLGB, AMP, MMG, JCNG, 
1 ECF, LEBC. LEBC reviewed the final manuscript. All authors contributed to multiple

2 revisions and approved the final manuscript. An outline of the manuscript was

3 established during five meetings, at which the authors collectively drafted and ranked

4 the discussion topics and challenges.

\section{Acknowledgements}

7 The authors appreciate the help received of paramedical staff of the Santiago General

8 hospital "Dr. Juan Bruno Zayas Alfonso". JCCR, SCAB, MPR, BLR and LEBC thank

9 to Universidad de Ciencias Médicas, Santiago de Cuba. TTBL and JLGB recognize the

10 financial support of the Universidad de Santo Domingo, República Dominicana.

\section{Authors' information (optional)}

13 'Servicio de Neumología, Hospital General Santiago "Dr. Juan Bruno Zayas Alfonso",

14 Santiago de Cuba, Cuba. ${ }^{2}$ Universidad de Oriente, Facultad de Ciencias Naturales,

15 Departamento de Farmacia, Santiago de Cuba, Cuba. ${ }^{3}$ Universidad Autónoma de Santo

16 Domingo, Recinto Nagua, Departamento de Ciencias, Escuela de Física, República

17 Dominicana. ${ }^{4}$ Técnica Regional del Ministerio de Educación, Nagua, República

18 Dominicana. ${ }^{5}$ Servicio de Medicina Interna, Departamento de Ensayos Clínicos,

19 Hospital General Docente Provincial Saturnino Lora, Santiago de Cuba, Cuba.

$20{ }^{6}$ Universidad de Ciencias Médicas, Departamento de Fisiología, Santiago de Cuba,

21 Cuba. ${ }^{7}$ Universidad de Oriente, Facultad de Ciencias Naturales y Exactas,

22 Departamento de Matemática, Santiago de Cuba, Cuba. ${ }^{8}$ Unidad de Cuidado Intensivo,

23 Hospital General Docente Agostinho Neto, Guantánamo, Cuba. ${ }^{9}$ Universidad Autónoma

24 de Santo Domingo, Recinto San Francisco de Macorís, Departamento de Ciencias,

25 Escuela de Física, República Dominicana. ${ }^{10}$ Universidad de Oriente, Facultad de 
1 Ciencias Sociales, Santiago de Cuba, Cuba. ${ }^{11}$ Centro Provincial de Medicina Deportiva,

2 Santiago de Cuba, Cuba. ${ }^{12}$ Universidad de Oriente, Centro Nacional de

3 Electromagnetismo Aplicado, Departamento de Investigación e Innovación, Santiago de 4 Cuba, Cuba.

\section{References}

7 1. Cabo García A, del Campo Mulet E, Nápoles Smith N, González TR, Columbié

8 Regüeiferos JC. Aspectos clínicos y epidemiológicos en pacientes con cáncer de

9 pulmón en un servicio de neumología. MEDISAN. 2018;22(4):394. Available

10 from: http://scielo.sld.cu/scielo.php?script=sci_arttext\&pid=S1029-

$11 \quad 30192018000400009$.

12 2. Columbié Regüeiferos JC, Araujo Duran Y, Beatón EA, León BQ, García AC.

13 Asociación de los biomarcadores con el cáncer pulmonar en pacientes de un

14 servicio de neumología. MEDISAN. 2018;22(06):592-6. Available from: https://www.medigraphic.com/cgi-bin/new/resumen.cgi?IDARTICULO=80556.

16 3. González-Pérez I, Lavernia HHC, Pedro CR, Pérez AC, Monzón KL. Normalized serum EGF levels as a potential biomarker in non-small cell lung cancer: The role of platelets. J Mol Biomark Diagn. 2018;9(402):2. https://doi:0.4172/21559929.1000402.

4. Toso S, Piccoli A, Gusella M, Menon D, Bononi A, Crepaldi G, et al. Altered tissue electric properties in lung cancer patients as detected by bioelectric impedance vector analysis. Nutrition. 2000;16(2):120-4. https://doi:10.1016/S0899-9007(99)00230-0. 
1 5. Piccoli A. Bioelectric impedance measurement for fluid status assessment. In

$2 \quad$ Fluid Overload, Karger Publishers. 2010;164:143-52.

3 https://doi:10.1159/000313727.

4 6. Nwosu AC, Mayland CR, Mason S, Cox TF, Varro A, Ellershaw J. The association of hydration status with physical signs, symptoms and survival in advanced cancer-The use of bioelectrical impedance vector analysis (BIVA) technology to evaluate fluid volume in palliative care: an observational study. Plos One. 2016;11(9):e0163114. https://doi:10.1371/journal.pone.0163114.

7. Luna TTB, González MM, Jarque MV, González TR, Brooks SCA, Castañeda ARS, et al. Individualized body bioelectrical impedance parameters in newly diagnosed cancer children. Transl Med Commun. 2020;5(1):1-14. https://doi:10.1186/s41231-020-00062-1.

8. Lundberg M, Dickinson A, Nikander P, Orell H, Mäkitie A. Low-phase angle in body composition measurements correlates with prolonged hospital stay in head and neck cancer patients. Acta Oto-laryngol. 2019;139(4):383-7. https://doi:10.1080/00016489.2019.1566779.

9. Elia M. Body composition by whole-body bioelectrical impedance and prediction of clinically relevant outcomes: overvalued or underused? Eur J Clin Nutr. 2013;67(1):S60-70. https://doi:10.1038/ejcn.2012.166.

10. Williams JR. The Declaration of Helsinki and public health. Bulletin of the World Health Organization. 2008;86:650-2. https://www.scielosp.org/article/bwho/2008.v86n8/650-652/.

11. Buenas Prácticas Clínicas en Cuba. Centro para el Control Estatal de la Calidad de los Medicamentos. La Habana. Cuba. CECMED. 2000. Available from: https://www.google.com/url?sa=t\&rct=j\&q=\&esrc=s\&source=web\&cd=\&ved=2a 
hUKEwiIxfLsk9vxAhXVTjABHdYjBMYQFjAAegQIBxAD\&url=https\%3A\%2 F\%2Fwww.cecmed.cu\%2Ffile\%2F1984\%2Fdownload\%3Ftoken\%3DOeQm92f3 \&usg=AOvVaw2KRGkA8C5KqWnfmDlytS25.

12. Edge SB, Compton CC. American Joint Committee on Cancer of the AJCC Cancer Manual and the Future of TNM. Ann Surg Oncol. 2010;17(6):1471-4. https://doi:10.1245/s10434-010-0985-4.

13. Gutiérrez LCR, Nuviola JR, Polo LEH, Hechavarría MES, Brooks SCA, Mullings-Pérez R. Clinic-nutritional characterization in patients with lung cancer Saturnino Lora Hospital December 2015-March 2016. Rev Arch Hosp Universitario “General Calixto García”. 2017;5(2):156-71. Available from: http://www.revcalixto.sld.cu/index.php/ahcg/rt/printerFriendly/238/0.

14. González-Pérez I, Lavernia HHC, Pérez AC, Monzón KL. Measurement of serum EGF levels, a methodological approach: Learning what means "Low-/highconcentration of EGF in serum”. Some clinical implications. J Mol Biomark Diagn. 2017;8(3):1000335. https://doi:10.4172/2155-9929.1000335.

15. Nescolarde L, Núñez A, Bogónez-Franco P, Lara A, Vaillant G, Morales R, et al. Reference values of the bioimpedance vector components in a Caribbean population. e-SPEN J. 2013;8(4):e141-4. https://doi:10.1016/j.clnme.2013.04.004.

16. Akoglu H. User's guide to correlation coefficients. Turk J Emerg Med. 2018;18(3):1-3. https://doi:10.1016/j.tjem.2018.08.001.

17. Smith IL. The eta coefficient in MANOVA. Multivariate Behav Res. 1972;7(3):361-72. https://doi:10.1207/s15327906mbr0703_6.

18. Johnstone IM, Lu AY. On consistency and sparsity for principal component analysis in high dimensions. J Am Stat Assoc. 2009;104(486):682-93. https://doi:10.1198/jasa.2009.0121. 
1 19. Díaz Toledo M, Cayón Escobar I, Crespo Díaz TT, Fernández Norma L, Valladares Carmen R. Quimioterapia en cáncer de pulmón avanzado en pacientes mayores de 60 años de edad del Hospital Benéfico-Jurídico (2008-2011). Rev Haban Cienc Med. 2014;13(2):227-37. Available from: http://scielo.sld.cu/scielo.php?pid=S1729519X2014000200008\&script=sci_arttext\&tlng=en.

20. Sakuragi T, Oshita F, Nagashima S, Kasai T, Kurata T, Fukuda M, et al. Retrospective analysis of the treatment of patients with small cell lung cancer showing poor performance status. Jpn J Clin Oncol. 1996;26(3):128-33. https://doi:10.1093/oxfordjournals.jjco.a023195.

21. Rodriguez-Lara V, Hernandez-Martinez JM, Arrieta O. Influence of estrogen in non-small cell lung cancer and its clinical implications. J Thorac Dis. 2018;10(1):482. https://doi:10.21037/jtd.2017.12.61.

22. Cerchietti L, Navigante A, Sauri A, Palazzo F. Hypodermoclysis for control of dehydration in terminal stage cancer. Int J Palliat Nurs. 2000;6(8):370-4. https://doi:10.12968/ijpn.2000.6.8.9060.

23. Hamid AA, Issa MB, Nizar NNA. Hormones. In Preparation and Processing of Religious and Cultural Foods. Edited by: Md. Eaqub Ali and Nina Naquiah Ahmad Nizar (pp. 253-277). Woodhead Publishing, ELSEVIER. 2018. https://doi.org/10.1016/B978-0-08-101892-7.00013-4.

24. Chooi YC, Ding C, Magllos F. The epidemiology of obesity. Metabolism. 2019;92:6-10. https://doi: 10.1016/j.metabol.2018.09.005.

25. Cone CD Jr, Tongier M Jr. Contact inhibition of division: involvement of the electrical transmembrane potential. J Cell Physiol. 1973;82(3):373-86. https://doi:10.1002/jcp.1040820307. 
1 26. Mirbeik-Sabzevari A, Tavassolian N. Tumor detection using millimeter-wave technology: Differentiating between benign lesions and cancer tissues. IEEE Microw Mag. 2019;20(8):30-43. https://doi:10.1109/MMM.2019.2915472.

27. Li R, Liu B, Liu Y, Liu Y, He Y, Wang D, et al. Elevated serum lipid level can serve as early signal for metastasis for non-small cell lung cancer patients: A retrospective nested case-control study. J Cancer. 2020;11(23):7023. https://doi:10.7150/jca.48322.

28. Zhukova G, Shikhlyarova AI, Shirnina E, Zinkovich M, Maschenko N, Zlatnik E,et al. Characteristics of the psychosomatic state of patients with lung cancer. Ann Oncol. 2018;29:viii561. Available from: https://www.annalsofoncology.org/.

29. Nicolis G, Prigogine I: Self Organization in Non-Equilibrium Systems. J Wiley and Sons New York. 1977, Chaps. III and IV.

30. Farsaci F, Tellone E, Galtieri A, Ficarra S. Thermodynamics characterization of lung carcinoma, entropic study and metabolic correlations. Fluids. 2020;5(4):164. https://doi:10.3390/fluids5040164.

31. Farsaci F, Tellone E, Galtieri A, Ficarra S. A thermodynamic characterization of the phenomena evolving in cancer pathology by dielectric relaxation in blood: A new approach by construction of TTM (Thermodynamic Tumor Matrix). J Mol Liq. 2020;316:113839. https://doi:10.1016/j.molliq.2020.113839.

\section{Figures}

Fig.1. Projections of the observations in the component plane (graph of the second principal component against the first principal component). (a) Influence graphic for $\mathrm{R}$ and Xc. (b) Score graphic for R and Xc. (c) Influence graphic for R/H and Xc/H. (d) Score graphic for $\mathrm{R} / \mathrm{H}$ and $\mathrm{Xc} / \mathrm{H}$. (e) Influence graphic for $\mathrm{R} / \mathrm{H}^{2}$ and $\mathrm{Xc} / \mathrm{H}^{2}$. (f) Score 
1 graphic for $\mathrm{R} / \mathrm{H}^{2}$ and $\mathrm{Xc} / \mathrm{H}^{2}$. The variables in the influence graphs (Figures 1a, c, e)

2 represented age $\left(X_{1}\right)$, gender $\left(X_{2}\right)$, patient weight $\left(X_{3}\right), H\left(X_{4}\right), \theta\left(X_{7}\right)$, degree of ECOG

3 functional scale $\left(\mathrm{X}_{8}\right)$, tumor stage $\left(\mathrm{X}_{9}\right)$, tumor histological variety $\left(\mathrm{X}_{10}\right)$, BMI $\left(\mathrm{X}_{11}\right)$. The

4 variable $\mathrm{X}_{5}$ symbolized R (Figure 1a), R/H (Figure 1c) and R/H $\mathrm{H}^{2}$ (Figure 1e). The

5 variable $\mathrm{X}_{6}$ denoted $\mathrm{Xc}$ (Figure 1a), $\mathrm{Xc} / \mathrm{H}$ (Figure 1c) and $\mathrm{Xc} / \mathrm{H}^{2}$ (Figure 1e). In the

6 score graphics were represented the name initial of each patient corresponding to its

7 code showed in Table 1: Code 1 (NPB), Code 2 (OMR), Code 3 (NHB), Code 4 (RSF),

8 Code 5 (LGT), Code 6 (HMR), Code 7 (MBZ), Code 8 (ODR), Code 9 (OGC), Code 10

9 (JIRB), Code 11 (EGM), Code 12 (EPI), Code 13 (ITR), Code 14 (JRL), Code 15

10 (VTT), Code 16 (JCRO), Code 17 (RMP), Code 18 (ECP), Code 19 (EGC), Code 20

11 (NLB), Code 21 (OSP), Code 22 (CPI) and Code 23 (RGF). Patients with initials NHB,

12 OSP, NLB, EGM, ECP, EGC, LGT, ITR, RSF, JLR, ODR, OGC and OMR deceased

13 during the writing of this paper (Figures $1 b, d, f)$. The patient OMR died by global heart

14 failure.

16 Tables

17 Table 1 Characteristic variables in each newly diagnosed lung cancer adult patient

19 Table 2 Mean \pm standard error of the mean of sEGF, CYFRA21-1, and CA 72-4 tumor

20 marker values for apparently healthy subjects and newly diagnosed lung cancer adult

21 patient

23 Table 3 Mean \pm standard deviation (standard error of the mean) of $\mathrm{R} / \mathrm{H}, \mathrm{Xc} / \mathrm{H}$ and $\theta$

24 (newly diagnosed lung cancer adult patients) and $(\mathrm{R} / \mathrm{H})_{\mathrm{r}},(\mathrm{Xc} / \mathrm{H})_{\mathrm{r}}$ and $\theta_{\mathrm{r}}$ (apparently

25 healthy subjects), by age group and gender 
2 Table 4 Spearman's rho correlation $\mathrm{r}$ (probability $\mathrm{p}$ ) for each pair of variables analyzed 3

4 Table 5 Eta correlation coefficients

5

6 Table 6 Eigenvalues and eigenvectors of the correlation matrix of 11 independent

$7 \quad$ variables considering $\mathrm{R}$ and $\mathrm{Xc}$

8

9 Table 7 Eigenvalues and eigenvectors of the correlation matrix of 11 independent

10 variables considering $\mathrm{R} / \mathrm{H}$ and $\mathrm{Xc} / \mathrm{H}$

11

12 Table 8 Eigenvalues and eigenvectors of the correlation matrix of 11 independent

13 variables considering $\mathrm{R} / \mathrm{H}^{2}$ and $\mathrm{Xc} / \mathrm{H}^{2}$

14 

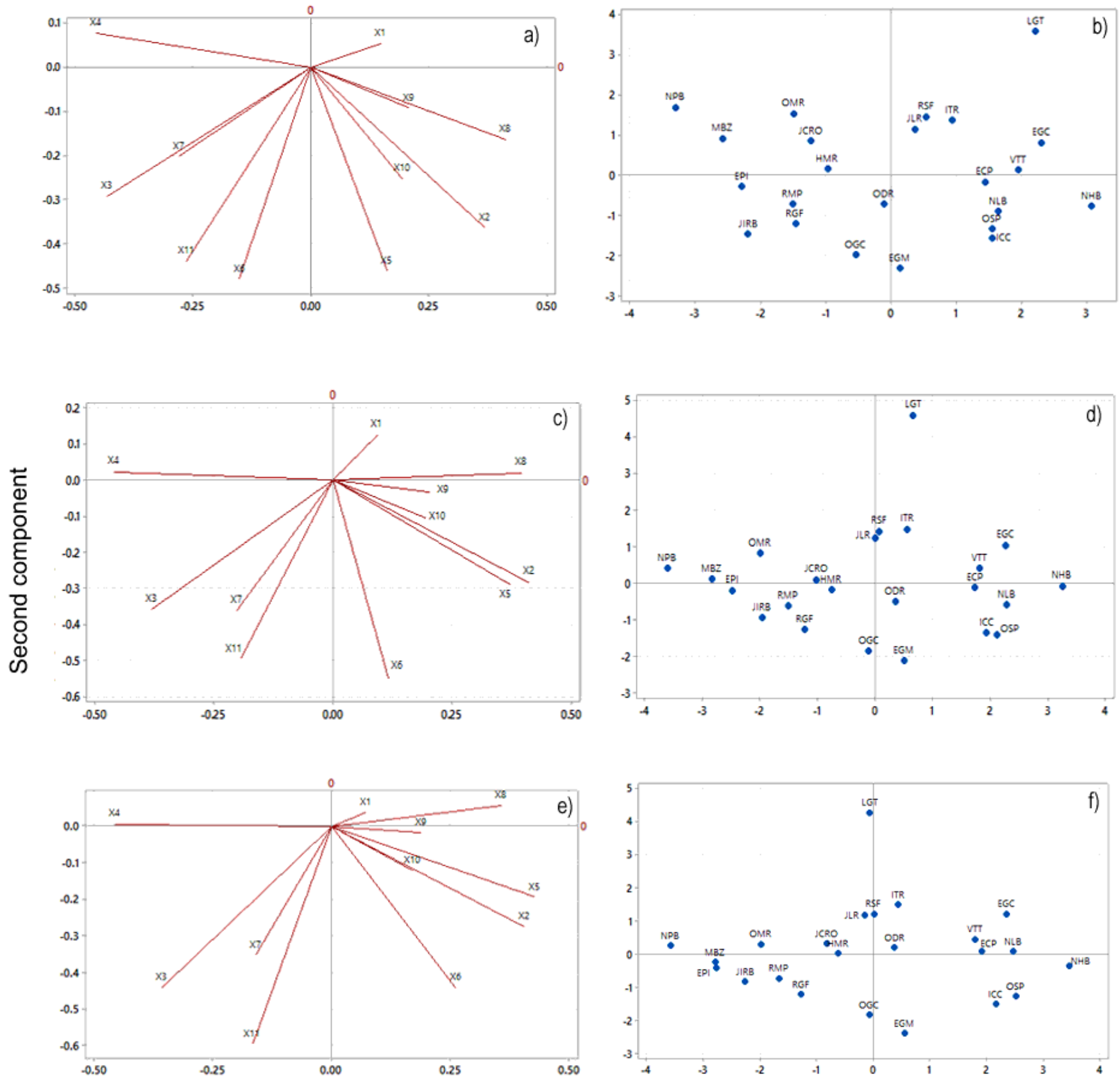

First component

\section{Figure 1}

Projections of the observations in the component plane (graph of the second principal component against the first principal component). (a) Influence graphic for R and Xc. (b) Score graphic for R and Xc. (c) Influence graphic for $\mathrm{R} / \mathrm{H}$ and $\mathrm{Xc} / \mathrm{H}$. (d) Score graphic for $\mathrm{R} / \mathrm{H}$ and $\mathrm{Xc} / \mathrm{H}$. (e) Influence graphic for $\mathrm{R} / \mathrm{H}^{2}$ 
and $\mathrm{Xc} / \mathrm{H}^{2}$. (f) Score graphic for $\mathrm{R} / \mathrm{H}^{2}$ and $\mathrm{Xc} / \mathrm{H}^{2}$. The variables in the influence graphs (Figures $1 \mathrm{a}, \mathrm{c}, \mathrm{e}$ ) represented age $\left(X_{1}\right)$, gender $\left(X_{2}\right)$, patient weight $\left(X_{3}\right), H\left(X_{4}\right), q\left(X_{7}\right)$, degree of ECOG functional scale $\left(X_{8}\right)$, tumor stage $\left(X_{9}\right)$, tumor histological variety $\left(X_{10}\right)$, $B M I\left(X_{11}\right)$. The variable $X_{5}$ symbolized $R$ (Figure $\left.1 a\right)$, $\mathrm{R} / \mathrm{H}$ (Figure $1 \mathrm{c}$ ) and $\mathrm{R} / \mathrm{H}^{2}$ (Figure 1e). The variable $\mathrm{X}_{6}$ denoted $\mathrm{Xc}_{\mathrm{c}}$ (Figure 1a), $\mathrm{Xc} / \mathrm{H}$ (Figure 1c) and $\mathrm{Xc} / \mathrm{H}^{2}$ (Figure 1e). In the score graphics were represented the name initial of each patient corresponding to its code showed in Table 1: Code 1 (NPB), Code 2 (OMR), Code 3 (NHB), Code 4 (RSF), Code 5 (LGT), Code 6 (HMR), Code 7 (MBZ), Code 8 (ODR), Code 9 (OGC), Code 10 (JIRB), Code 11 (EGM), Code 12 (EPI), Code 13 (ITR), Code 14 (JRL), Code 15 (VTT), Code 16 (JCRO), Code 17 (RMP), Code 18 (ECP), Code 19 (EGC), Code 20 (NLB), Code 21 (OSP), Code 22 (CPI) and Code 23 (RGF). Patients with initials NHB, OSP, NLB, EGM, ECP, EGC, LGT, ITR, RSF, JLR, ODR, OGC and OMR deceased during the writing of this paper (Figures $1 b, d, f)$. The patient OMR died by global heart failure. 